\title{
An Attempt of Reconciliation over History: The Case of the 1871 Ryukyu Shipwreck Incident
}

\author{
Mizuno Norihito
}

\begin{abstract}
The aim of this article is to search for possible solutions for history-related friction between Japan and its neighbors. The so-called Ryukyu Shipwreck Incident, also known as the Mudan Incident in English, occurred in December 1871; when 54 shipwrecked Ryukyuans were massacred by Taiwanese aborigines. The incident gave Japan a pretext for its first overseas military action of the modern period toward the Taiwanese aboriginal territories in 1874. Since shortly after the beginning of the twenty-first century, the descendants of both the assaulters and the victims of the massacre have begun to take a step toward reconciliation. This article focuses on the local quest of Japan and Taiwan for reversing the damage caused by the history of recent years, and discusses the potential along with the limitations which this local attempt indicates, in terms of settling the discord over history between Japan and its neighbors.
\end{abstract}

Index Terms-1871 Ryukyu shipwreck incident, history dispute, Miyakojima, Taiwanese aborigines.

\section{INTRODUCTION}

History has been one of the primary factors causing tension between Japan and its neighboring countries in recent decades. On both official and nonofficial levels, various attempts have been made toward reconciliation over the past. This article pays attention to a local quest for reconciliation. In December 1871, 54 shipwrecked residents of the Miyakojima Islands and the Yaeyama Islands were cast upon the southeastern shore of Taiwan and massacred by the aboriginal tribesmen of Kuskus (Gaoshifo), part of the Paiwan people. More than two years after the incident, the Meiji government, which had started to resolve the dual subordination of the kingdom to China and Japan and incorporate the entire Ryukyu Islands into Japan, launched a military expedition against the Taiwanese aborigines on the pretext of the protection of their people under Japanese sovereignty. The invasion of the Japanese forces into the aboriginal territories, part of the present-day Mudan Township, brought about military confrontations with the local tribesmen of the Kuskus and another Paiwan tribe, the Sinvaudjan (Mudan). After about one hundred and thirty years had passed since the massacre, the descendants of the assaulters and the victims began to take action toward reconciliation in the very beginning of the first decade of this century. This article will first trace how the residents of Miyakojima and the native Taiwanese of Mudan Township have associated with each other and tried to deal with the past

Manuscript received September 15, 2013; revised November 19, 2013.

N. Mizuno is with the Akita International University, Akita-shi, Akita 010-1425 Japan (e-mail: nmizuno@ aiu.ac.jp). over the last ten years, and discusses the potential and the limitations found in the local experience.

\section{THE 1871 RYUKYU SHIPWRECK INCIDENT AND ITS AFTERMATH}

The incident, also known as other names such as the Bayao Bay (Bayaowan) Incident, occurred when shipwrecked Ryukyuans drifted ashore on the southeastern coast of Taiwan. On November 30, 1871, four Ryukyus ships -- two ships from Miyakojima Island and two others from Yaeyamajim Island-- were on their way from Okinawa Island back home, and while paying annual tribute by means of a pole tax to Naha, the capital of the Kingdom of Ryukyu (1429-1879), they encountered a tempest. One of the Miyakojima ships carried 69 crew members. Three of them were drowned, and 66 were cast ashore on December 17. The area where those survivors landed was the residential area of one of the tribes of the Paiwan people; Kuskus (Gaoshifo). Shipwrecked foreigners had been repeatedly maltreated or massacred by the aboriginal tribesmen, and the Ryukyuans followed the same fate. They were all captured (or protected) by the tribesmen, but some of them attempted to escape. As a result, twelve were able to escape and make it back home. These twelve were rescued by local Chinese settlers and put under the protection of the officials of the Fujian Province, which Taiwan was administratively integrated into. They were thereafter sent back to the Ryukyu House - the branch facility of the kingdom as a Chinese tributary state -- in Fuzhou in February 1872, and returned to Naha in July. The Ryukyu King, Sho Tai (r. 1866-1872) expressed his gratitude by sending a reward to the Fujian Province. On the other hand, however, the rest of the shipwrecked Ryukyuans, namely 54 of them, did not survive. They were recaptured and beheaded by the tribesmen [1].

This incident gave rise to a retaliatory military action against the Taiwanese aborigines. The incident was reported from Naha in the summer of 1872, some government officials and military officers started to demand the dispatch of troops overseas in Kagoshima Prefecture. Before the new imperial regime seized power by the last warrior regime, Tokugawa Bakufu (1603-1868) and the prefectural system in 1871, the prefecture was Satsuma Domain (han) and subordinated the Kingdom of Ryukyus since the military conquest in 1609. When the Ryukyu Shipwreck Incident occurred, the insular kingdom had been in a state of dual-subordination to China and Japan [1]. In the changing international environment of the late nineteenth century, Japan had been getting concerned over the legal status of the Ryukyus, in terms of modern (Western) international law. For the local officials and officers who had been Satsuma retainers, it should have been 
quite a natural conclusion that their traditional sway over the Ryukyus should not have been not renounced, but adjusted to the world of Western predominance. And the proposed military expedition to Taiwan would accordingly have the meaning of the demonstration of Japanese sovereignty over the Ryukyus [1].

The punitive expedition against the Taiwanese aborigines won support in Tokyo, and was carried out in the spring of 1874. With the Chinese statement that the Taiwanese aboriginal territories were beyond China's control, obtained from the Zongli Yamen in 1873, the Japanese government dispatched over 3,600 soldiers to the aboriginal territories in April 1874; despite the objection from Western powers. Besides the issue of the legal status of the Ryukyus, it is believed that the Japanese expected an overseas military campaign, since the new regime came to power to remedy the worsening domestic problem; namely the mounting discontentment of ex-warriors against the new regime and to obtain the aboriginal territories, which were not regarded as anyone's possession after the talks with the Zongli Yamen. These three motives for the first overseas expedition after the new regime came to power were by no means unrelated to one another, and all derived from Japan's concern over national security in the situation of the inroad of Western imperialist powers in East Asia [1].

Battles between the Japanese troops and the Taiwanese aborigines broke out soon after the landing of the expeditionary forces in late May 1874, and virtually ceased in early June. The advanced Japanese troops landed on the southwestern coast of Taiwan, where the National Museum of Marine Biology and Aquarium is located today, on May 6. The Japanese soon discovered that Kuskus had massacred the 54 Ryukyuans, but also regarded Sinvaudjan, who showed the posture of resistance, as an accomplice. A series of skirmishes broke out in mid and late May. The main body of the expeditionary forces, consisting of over 3,600 officers and soldiers, led by Saigo Tsugumichi landed on May 22. On the same day, a major clash called the Battle of Shimen occurred. The Japanese forces started to attack the base of Sinvandjan on June 1, and returned back to the headquarters several days later. Having continued resistance for several more weeks, the two tribes surrendered to the Japanese on July 1 [2].

Despite the virtual end of military operations, the Japanese troops remained until the end of the year because their invasion of the aboriginal territories caused a diplomatic dispute between Japan and China. The expeditionary forces did not withdraw from Taiwan until the diplomatic negotiations in Beijing were settled. The Japanese justified the military campaign as a righteous action to protect their own people in no man's land, while the Qing Dynasty (1644-1912) claimed that the Japanese expedition was an encroachment on their territories. Negotiations between the two countries were made in Shanghai and Taiwan, and continued in Beijing until a peace settlement was made with British mediation on the last day of October, 1874. The Japanese troops withdrew in exchange for Chinese payment of 500,000 taels for Japanese military expenditures and the provision of money as an expression of condolence and mercy for the Japanese victims of the atrocities committed by the Taiwanese aborigines [1], [3].

The Ryukyu Shipwreck Incident and the subsequent Japanese expedition to the aboriginal territories brought many human and economic losses. Besides the 54 victims of the shipwreck incident, nearly 573 of over 3,600 soldiers died during the campaign in Taiwan. Although only 12 were killed in battle, 561 died of malaria [4]. In 500,000 taels, 400,000 (about 540,000 yen) was paid for Japan's expense for the overseas expedition but was by no means enough to compensate the total expenses which had amounted to $7,710,000$ yen [5]. The tragedy which befell the shipwrecked Ryukyuans, continues to be engraved in the memories of their families and descendants [6]. Meanwhile, it is believed that 38 tribesmen of the Kuskus and Sinvandjan, including the chieftain of the latter tribe and his son were killed, and that their villages were devastated [net]. The survivors and their descendants have passed down through the generations, their families' and ancestors' resistance against the Japanese invaders as a tribal saga. For them, however, the hardship which their families and ancestors went through in 1874, has simultaneously continued to be an unforgettable memory [2], [7].

\section{THE MIYAKOJIMA-MUDAN SEARCH FOR RECONCILIATION}

It was Taiwan who took the first step toward reconciliation. In May 2002, the first commemorative ceremony took place on the Shimen battlefield. The reexamination of the Ryukyu Shipwreck Incident and the subsequent Japanese expedition to the Taiwanese aboriginal territories had been ceased under the dictatorship of the Chinese Communist Party (KMT) in the postwar period. It was the democratization of the Taiwanese society that enabled the opening of such a public ceremony [8]. In November 2004, the international symposium on the incident took place in the Mudan Township Office as a Japanese-Taiwanese joint event for the $130^{\text {th }}$ anniversary of the Japanese expedition to the aboriginal territories [8], [9]. The Mudan Township Mayor, Lin Jiexi, talked at that time, "It is our role to reconcile with and promote interchanges with Japan based on the investigation of historical facts, along with being grateful to the ancestors who protected our homeland." In the annual commemoration ceremony on the Shimen battlefield on May 29, 2005, Lin furthermore launched a five year project to make the historical site into a memorial park to pass down the incident to future generations, spending 120 million Taiwan dollars [8].

Commemoration was also accompanied by more direct actions toward reconciliation. In 2004, Yang Mengze, a professor in art education at the National Taipei University of Education, and the descendants of the Paiwan (Gaoshifo) tribesmen involved in the 1871 massacre, visited Miyakojima to express their apologies to the descendants of the massacred victims [9]. In the abovementioned symposium, one of the participants, as the representative of the Paiwan people, apologized for the massacre. A Japanese participant, Matayoshi Seikiyo of Okinawa University, also expressed his apology for the Japanese military campaign in 1874 [10]. On June 15, 2005, 18 Mudan residents, including Township 
Mayor Lin Jiexi, went on a four-day tour to Okinawa for the purpose of reconciliation. On June 16, Lin and his party visited the memorial of the victims of the massacre at Gokokuji Templein in Naha; and Bai Yongmu and Hua Acai met with Nakasone Genji from Oita Prefecture. Nakasne is the descendant of Nakasobe Gen'an, the highest-ranking victim of the massacre and the chief administrator (kashirashoku) of Miyakojima Island. Nakasone exchanged handshakes with the two native Taiwanese, and appreciated their visit to Okinawa [11]. They arrived in Miyakojima on June 17. Lin had a meeting with Mayor Ishimine Akira and asked for friendship and exchanges between Mudan and Miyakojima to move beyond the past. On the following day, along with the Mayor and Kugai Katumori, the superintendent of the local board of education and the eight descendants of the victims of the massacre welcomed the Taiwanese visitors [12]. Lin recalled that although there may have been a person (or people) that might have been angry at the beginning, a mutual understanding has been gradually deepened [8].

Exchanges between Mudan and Okinawa, including Miyakojima, continued. On August 27, 2005, 22 students of Okinawa University led by Matayoshivisited Mudan to participate in the cultural event. In the opening ceremony, Lin stated that they would have to not only find the truth (of the past), but also dissolve the historical grudge [13]. Matayoshi responded by mentioning that he hoped that exchange between Mudan and Ryukyus would continue, and that both parties would maintain a long friendship and forget the grief of the past [13]. On December 6, 2007, with the attendance of the Magistrate of Pingtung County, Cao Qihong, Lin Jiexi, and the Mayor of Miyakojima City, Ishimine Akira, met on the Shimen Battlefield, where the unveiling ceremony took place for the "Love \& Peace" monument to the memory of the battle with the Japanese forces in 1874; which was presented to Miyakojima [14].

In the year of the $140^{\text {th }}$ anniversary of the Ryukyu Shipwreck Incident, a series of events hosted by the government organization of the Council for Cultural Affairs of the Executive Yuan, took place for commemoration in Taiwan. On November 23, a ceremony for reconciliation and a news conference were held with the attendance of the three descendants of those who were involved in the massacre. Hua Acai (Valjulk Mavaliu) is the ex-Mudan Township Mayor, and the descendant of the Gaoshifo tribesmen involved in the massacre. Nohara Koei is a karate instructor in Urasoe, Okinawa and the descendant of the massacre victim Nohara Chamu. Yang Xinde is the descendant of the Chinese man who protected the survivors of the massacre. In the afternoon of November 25, a memorial service was held in the tomb of the Ryukyuans, located in Checheng [15]. On the 26, an international academic conference was held in the National Museum of Marine Biology and Aquarium, located near the point where the Japanese expeditionary forces landed in 1874 [16].

\section{The Potential AND Limitations OF THE MIYAKOJIMA -MUDAN RECONCILIATION}

History has been the cause of diplomatic and popular frictions between Japan and a few of its neighboring countries in the most recent past few decades. The first major case of international dispute over history occurred in the summer of 1982. There was extensive Japanese media coverage as a result of the Japanese Education Ministry's screening of high school history textbooks that drew not only domestic, but also regional international attention among its East Asian neighbors and ignited the criticism that the Japanese government tried to distort or even whitewash the country's past misconducts before the end of the Second World War. The media coverage that the Education Ministry ordered a publisher to replace the term "aggression (shinryaku)" with "inroad (shinshutsu)" was false, and major Japanese newspapers thereafter admitted their mistake [17]. However, disputes over Japanese history textbooks at home and with the neighboring countries have sporadically occurred [18]. The Japanese Prime Minister's visit to the Yasukuni Shrine has also been the cause of another history-related international tension with the neighbors. The Shinto Shrine preserves more than 2.4 million Japanese soldiers, along with those who lost their lives in the domestic upheavals of the 1850s and 1860s, and the Class-A war criminals of the International Military Tribunal for the Far East. The presence of those war criminals in the shrine seems to especially jar on the nerves of the countries which recognize themselves as the victims of Japanese colonialism and expansionism [19].

Tension between East Asian countries over the past has recently become entangled with territorial disputes and seemed to get even more intensified; it is not true that Japan and its neighbors have done nothing in the last few decades. They have made some attempts to put an end to the history disputes between the neighboring countries. When the first history textbook issue occurred in 1982, the Japanese government tried to ease the anger of its neighbors by adding the so-called Neighboring Countries Clause (kinrin shokoku joko) as a criterion; which requires publishers to write junior high and high school history textbooks in consideration of its neighbors [20]. Since the late 1980s, more and more Japanese premiers have avoided visiting the Yasukuni Shrine. Under the political initiative of the Japanese and South Korean governments, the Japan-South Korea Joint History Research Project was initiated in 2002, because Japanese and Korean scholars had debated on a variety of themes about the history of Japanese-Korean relations, and history textbooks have made two reports in 2005 and 2010 [21]. In the same way, in 2006, the Japanese and Chinese governments initiated the Japan-China Joint History Research Committee, which repeated several meetings until 2009, and made a report in 2010 [22]. It goes without saying, however, that these projects have made no contribution to the settlement of the history disputes, which remain to be one of the primary causes of discord between Japan and its neighbors.

At around the same time as the above-mentioned central government-initiated projects, the local pursuit of conciliation demonstrated certain progress, with the sharing of recognition of a historical fact between the descendants of the assaulters and the victims. Neither of them challenged the point that the massacre of 54 shipwrecked sailors was committed by Kuskus tribesmen; Taiwan's recognition of 
and apology for their ancestors' actions elicited pardon from the descendants of the victims of the massacre.

Consensus on historical facts may thus be important to resolve history-related disputes. Matayoshi Seikiyo has been an active pivotal figure in the reconciliation effort on the side of the Japanese, emphasizing the importance of nonofficial grass root-level interchanges to promote reconciliation and amity [23]. However, in the Miyakojima-Mudan case, it should be noteworthy that the local government authorities of both parties have played important roles, and sometimes taken initiatives. That is, this local case might indicate a possibility that emotional estrangement caused by past events could be resolved if the recognition of facts can be formed and shared; no matter who takes initiative in an attempt for reconciliation.

The recognition of historical facts depends on fact finding, which is by no means easy. Human knowledge of history is often like a puzzle with missing pieces, which will inevitably generate conflicting arguments among historians. "Taking history as a mirror" has been a popular phrase in the history controversy. Chinese leaders such as Jiang Zemin, Hu Jingtao, and Wen Jiabao have repeatedly emphasized this phrase toward the Japanese [24]-[26]. When it is cracked or has missing parts, a mirror cannot project the whole picture of a historical event, and disputes over the recognition of historical facts from history will continue. Finding historical facts is indeed one crucial aspect of the history controversy between Japan and its neighbors. The Japanese and its neighbors have constantly been disputing over the recognition of historical facts; for example, over the Nanjing Incident (or the Rape of Nanjing) and the involvement of the Japanese government and military in the "enslavement" of Korean women as comfort women [27], [28].

Additionally, in the Miyakojima-Mudan case, both parties do not necessarily share the same understanding of the past, and in the aforementioned reconciliation ceremony on November 23, Nohara exchanged handshakes with Hua Yumin; the ex-Mudan township mayor and the descendant of the assaulter. Nohara mentioned, "The incident has already become history. I am overwhelmed by emotion [29].” Four days later, Nohara visited the Mudan Incident Memorial Park in Mudan Township and fixed his eyes on an illustrated board It explained that the 66 shipwrecked Ryukyuans were equipped with weapons, and therefore, their appearance in the tribal area caused the sense of pressure and fear in the local village. Nohara demanded that the explanation should be either deleted or removed for the reason that such an irresponsible explanation based on no convincing proof would cause the understanding that the victims, including his ancestor, were killed in the self-defense of the aboriginal tribes [30], [31].

Furthermore, sharing the common recognition of historical facts does not necessarily put an end to disputes over the past. Even if more than two parties share the common recognition of a historical fact, this does not automatically mean that they share the same interpretation of that fact. This is the other aspect of the history controversy between East Asian countries. For example, China and Japan recognize the Sino-Japanese War (1894-1895) as a historical fact, but they do not have consensus on the interpretation of the war. China takes the official stance that the outbreak of the war in 1894 marked the beginning of Japanese encroachment. On the other hand in Japan, there are various arguments, some of which refuse to define the war itself as that of aggression against China [32].

The presence of missing pieces of facts further generates a scope of different or even conflicting conjectures and interpretations. Difficulties with finding the facts of the past have been mostly due to the absence (or lack) of historical sources; the Ryukyu Shipwreck Incident is an example of this. There is no objection to the massacre itself as a historical fact, while the absence of written records keeps the cause of the massacre unknown, but simultaneously provides room for free conjectures. The aboriginal tribes have inherited orally transmitted narratives, which can be barely regarded as convincing source materials. Hua Acai claims that linguistic and cultural barriers have caused misunderstandings between the Kuskus tribesmen and the shipwrecked Ryukyuans regarding the tragedy [16]. However, not only is there no way to prove this narrative, but there are also other interpretations that contradict Hua's [6].

It is noteworthy that democratization in Taiwan brought the aboriginal people a chance to reexamine and speak out about their tribal past; however, it could be a double-edged sword to the controversy over the history. In the Miyakojima-Mudan case, more freedom of speech perhaps urged the aboriginal people to take steps toward reconciliation. There is no reason to deny the possibility that as a result of democratization, China will follow Taiwan's precedent; however, it may be too naive to expect what the Japanese case so excessively indicates. In the country, democracy has generated diversified views of history, and it is quite unlikely that they will be converged at a certain direction to conform to the neighbors. Another possibility is that democratization could further stimulate nationalism and drive the public's view of history into a more uncompromising direction.

If Japan could learn something from the German's case, it is that legal measures rather than either individual or collective scholarly efforts might be effective to cope with the antagonistic relations with the neighbors over the history. In the ex-Axis power, which is often compared to the other ex-Axis power, legal measures have been applied to history-related issues; as the denial of the Holocaust is for example criminalized by Article 130 of the Penal Code [33]. This sort of legal control eliminates certain historical discourses and interpretations. As a result, domestic and international disputes over history issues might cool down to some extent. It is quite questionable, however, that the German approach will win popular support in the current domestic popular sentiment, however, the neighbors are getting bored of keeping a low profile about the historical issues.

\section{CONCLUSION}

Mudan Township and Miyakojima Island have worked for reconciliation and friendship for the last ten years. Rapprochement was made when both parties shared a common recognition of the massacre of 1871 as an 
undeniable historical fact, and when apology and tolerance were exchanged between them. The local experience might be suggestive to the controversy over history between Japan and its neighboring countries. The applicability of the Mudan-Miyakojima case to others will be diminished, however, when the recognition of the facts is the cause of controversy. The sharing of historical facts would not automatically guarantee the sharing of interpretation of the facts. In fact, the residents of Mudanan and Miyakojima do not necessarily have completely the same recognition and interpretation of historical facts, as it was revealed in the $140^{\text {th }}$ anniversary year of the massacre. History should be taken as a mirror. There has been little scope of objection to this idea. Nevertheless, the mirror is seldom an integer, which causes collision over historical facts. Even if the mirror has no missing pieces, what it projects might not necessarily have the same perception. Although forcible creation of common recognition and interpretation of history could be an alternative, it might not be able to materialize without an even more calamitous tragedy than the 1871 massacre, and a subsequent Japan-Taiwan military conflict.

\section{REFERENCES}

[1] N. Mizuno, "Early Meiji policies toward the Ryukyus and the Taiwanese aboriginal," Modern Asian Studies, vol. 43, no. 3, pp. 682-639, May 2009.

[2] P. Lianes, "Sinvaudjan kara mita Botansha JIken jo (cong Sinvandjan kan Mudanshe Shijian)," Satoi Yoichi Trans Ryukyu Daigaaku Kyoiiku Gakubu Kiyos, vol. 72, pp. 41-63, Mar. 2008.

[3] N. Mizuno, "Qing China's reaction to the 1874 Japanese expedition to the Taiwanese aboriginal territories," Sino-Japanese Studies, vol. 16, no. 5, pp. 100-125, 2009.

[4] S. Tokutomi, Kinsei Nihon Kokuminshi 90: Taiwaneki Shimatsu Hen, Tokyo: Kinsei Nihon Kokuminshi Kankokai, 1961, pp. 386.

[5] T. Mori, Taiwan Shuppei: Dai Nippon Teikoku no kaimakugeki, Tokyo; Chuo KOron Shinsha, 1996, pp. 170.

[6] Y. Satoi, "Miyakojima Taiwan Sonan JIken: seizonsha no shison ga ima ni tsutaeru mono," Rekishi to Jissen, vol. 30, pp. 339-47, Feb. 2011

[7] P. Lianes, "Sinvaudjan kara mita Botansha JIken ge (cong Sinvandjan kan Mudanshe Shijian)," Satoi Yoichi Trans Ryukyu Daigaaku Kyoiiku Gakubu Kiyos, vol. 73, pp. 27-50, Aug. 2008.

[8] H. Kurita. (June 28, 2009). Satsugai, hofuku, Nittai 'Botansha Jiken' 135-nen sangeki no senjo, koryu no ba ni. Tokyo Shinbun. [Online] Available:

http://www.tokyo-np.co.jp/article/world/news/CK2009062802000082 .html

[9] Y. Zhang. (November 23, 2011). Mudanshe Shijian jiazu da hejie. Yam News. [Online]. Available: http://n.yam.com/cna/garden/201111/20111123507199.html

[10] Y. Li. (June 9, 2005). Da hejie Paiwanzu qianjing Liuqiu. Yam News. [Online]. http://yam.und.com/yamnews/daily/2722858.shtml

Available:

1] R. Zhang. (June 17, 2005). Mudanshe Shijian 131-nian hou Tai-Ri weizu huimian min enchou. Zhongguo Shibao. [Online]. Available: http://news.chinatimes.com/Chinatimes/newslist/newslist-content/0,35 46,110501+112005061700026,00.html

[12] 'Wadakamari nakushi koryu o' homondan izoku to taimen: Botansha Jiken. Honjitsu no Nyusu. [Online]. Available: http://www.cosmos.ne.jp/ miyako-m/htm/news/ 050619.htm

[13] Y. Song. (August 28, 2005). Mudanshe Shijian: Tai-Ri Wumin Bainian hen. Yam News. [Online]. Available: http://yam.udn.com/yamnews/daily/2867504.shtml
[14] Z. Guo. (December 6, 2007). Mudanshe Shijian Jinianbei zeng Riben Chongsheng Gonggudaoshi. Yam News. [Online]. Available: http://news.yam.com/cna/garden/200712/20071206033408.html

[15] 140-Nianqian Mudanshe Shijian jiazu da hejie. Qing Qing Taolunqu. [Online]. Available: htttp://chch.idv.tw/phpwind/read.php?tid=18042

[16] 'Bayaowan Shijian' no izoku to kankeisha ga akai. Chuosha Fokasu Taiwan. [Online]. Available: http://japan.cna.tw/news/asoc/20111124001.aspx

[17] Y. Shimizu, Chugoku Wa Naze Hannichi Ni Nattaka, Tokyo: Bungei Shunju, 2003, pp. 113-117.

[18] K. Mori, Nitchu Kankei: Sengo Kara Shin Jidai He, Tokyo: Iwanami Shoten, 2006, pp. 122.

[19] Nihon no Zento to Rekishi Kyoiku o Kangaeru Wakate Giin no Kai ed., Rekishi Kyokasho e no Gimon: Wakate Kokkai Giin Ni Yoru Rekishi Kyokasho Mondai no Sokatsu, Tokyo: Nihon no Zento to Rekishi Kyoiku o kangaeru Wakate Giin noo Kai, 1997.

[20] 'Rekishi kyokasho' ni kansuru Miyazawa Naikaku Kanbo Chokan danwa. [Online]. http://www.mofa.go.jp/mofaj/area/taisen/miyazawa.html

[21] Nikkan Rekishi Kyodo Kenkyu. [Online]. Available: http://www/mofa.go.jp/mofaj/area/korea/ rekishi/

[22] Nitchu Rekishi Kyodo Kenkyu (gaiyo). [Online]. Available: http://www.mofa.go.jp/mofaj/aareaa/china/rekishi/

[23] Ryukyu Asahi Hoso Hodobu. (December 9, 2009). Q ripoto: Botansha Jiken 140-nenme no ireisai. Weather $Q ;$ News $Q+$. [Online]. Available: http://www/qad/co/jp/news/2011120932519.html

[24] Kawaguchi gaimu daijin: Ko Takumin kokka shuseki tono kaiken gaiyo. [Online]. Available: http://mofa.go.jp/mofaj/kaidan/g_kawaguchi/china_02/kotakumin.htl $\mathrm{m}$

[25] J. Wen. Yujo to kyoryoku no tame ni: Nihon Kokkai ni okeeru on Kaho sori no enzetsu. [Online]. Available: http://www.china-embassy-or.jp/jpn/zt/wjbzlfr/t311936.htm

[26] N. Kawamura, "Nitchu kankei no hatten katei: Nitchu shin kyoryoku taisei no kochiku," Nagoya gaikokugo Daigaku Gaikokugo Gakubu Kiyo, vol. 39, pp. 135-155, 2010.

[27] D. Askew, "The Contested Past: History and Semantics in the Nanjing Debate," Ritsumeikan International Affairs, vol. 2, pp. 63-78, 2004.

[28] I. Hata. (August 15, 2013). Rekishi ninshiki o meguru ronso: ianfu mondai to Nankin jiken. Dai 37-Kai Shin Sanmokukai Koenkai. [Online]. $\quad$ pp. 1-24. Available: http://jfn/josuikai.net/circle/shinsanmokukai/20130815hata.pdf

[29] Taiwan, Botansha Jiken 140-nen: ireisai de shisonra wakai no akushu. Sankei Nyusu. [Online]. Availability: http://sankei.msn.com/world/news/111125/chn11112521450006-n1.ht $\mathrm{m}$

[30] H. Miyagi. (Dec. 23, 2011). 'Botansha Jiken' setsumeiban tekyo o: 'buki motta' Miyako tomin. Ryukyu Shinpo. [Online]. Available: http://ryukyushimpo.jp/news/storyid-185516-storytopic-1.html

[31] 'Buki motta 66-nin' Botansha Jiken: Taiwan setsumeiban ni kijutsu Miyako shussshin izoku, sakujo motomeru. Miyako Mainichi Shinbun. [Online]. http://www.miyakomainichi.com/2011/12/28144/

[32] Z. Ni, "Tanaka naikaku ni okeru Chu-Nichi kokko seijoka to Ohira Masayoshi (sono 4)," Keizaigaku Ronshu, vol. 48, no. 3-4, pp. 63-96, March 2009.

[33] C. Safferling, "Europe as Transnational Law-A critical law for Europe: between national heritage and transnational necessities," German Law Journal, vol. 10, no. 10, pp. 1383-1398, 2010.

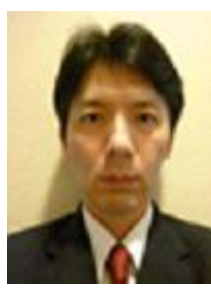

Mizuno Norihito has received $\mathrm{Ph} . \mathrm{D}$. He is an associate professor in the Global Studies Program at Akita International University, Akita, Japan. He was born in Nagoya, Japan and graduated from the Faculty of Law of Keio University, Tokyo, Japan. He earned Ph.D. in history at the Ohio State University, Columbus, $\mathrm{OH}$, USA. His field of specialty is Japanese-East Asian relations, especially Sino-Japanese relations. He is currently working on Japanese communities and educational institutions in China during the modern period. 